\title{
International organization:
}

\author{
a state of the art on an art of the state \\ Friedrich Kratochwil and John Gerard Ruggie
}

International organization as a field of study has had its ups and downs throughout the post-World War II era and throughout this century for that matter. In the interwar period, the fate of the field reflected the fate of the world it studied: a creative burst of work on "international government" after 1919, followed by a period of more cautious reassessment approaching the 1930s, and a gradual decline into irrelevance if not obscurity thereafter. Although they sometimes intersected, the fate of theory and the fate of practice were never all that closely linked after World War II. Indeed, it is possible to argue, with only slight exaggeration, that in recent years they have become inversely related: the academic study of international organization is more interesting, vibrant, and even compelling than ever before, whereas the world of actual international organizations has deteriorated in efficacy and performance. Today, international organization as a field of study is an area where the action is; few would so characterize international organizations as a field of practice.

Our purpose in this article is to try to figure out how and why the doctors can be thriving when the patient is moribund. To anticipate the answer without, we hope, unduly straining the metaphor, the reason is that the leading doctors have become biochemists and have stopped treating and in most cases even seeing patients. In the process, however, new discoveries have been made, new diagnostic techniques have been developed, and our understanding has deepened, raising the possibility of more effective treatment in the long run.

What we are suggesting, to pose the issue more directly, is that students of

The authors are grateful to Betty J. Starkey for bibliographical assistance, and to David Baldwin, Douglas Chalmers, Robert Jervis, Robert Keohane, Charles Lipson, Jack Snyder, and Mark Zacher for thoughtful comments on an earlier draft. 
international organization have shifted their focus systematically away from international institutions, toward broader forms of international institutionalized behavior. We further contend that this shift does not represent a haphazard sequence of theoretical or topical "fads" but is rooted in a "core concern" or a set of puzzles which gives coherence and identity to this field of study. ${ }^{1}$ The substantive core around which the various theoretical approaches have clustered is the problem of international governance. And the observable shifts in analytical foci can be understood as "progressive problem shifts," in the sense of Imre Lakatos's criterion for the heuristic fruitfulness of a research program. ${ }^{2}$ This evolution has brought the field to its current focus on the concept of international regimes. To fully realize its potential, the research program must now seek to resolve some serious anomalies in the regime approach and to link up the informal ordering devices of international regimes with the formal institutional mechanisms of international organizations.

In the first section of this article, we present a review of the literature in order to trace its evolution. This review draws heavily on articles published in International Organization, the leading journal in the field since its first appearance in 1947, and a source that not only reflects but in considerable measure is also responsible for the evolution of the field. The second section critiques the currently prevalent epistemological practices in regime analysis and points toward lines of inquiry which might enhance the productive potential of the concept as an analytical tool. Finally, we briefly suggest a means of systematically linking up regimes and formal organizations in a manner that is already implicit in the literature.

\section{Progressive analytical shifts}

As a field of study, international organization has always concerned itself with the same phenomenon: in the words of a 1931 text, it is an attempt to describe and explain "how the modern Society of Nations governs itself.", In that text, the essence of government was assumed to comprise the coordination of group activities so as to conduct the public business, and the particular feature distinguishing international government was taken to lie in the necessity that it be consistent with national sovereignty. Few contempo-

1. Thomas Kuhn uses the notion "sets of puzzles" in his discussion of preludes to paradigms; see Kuhn, The Structure of Scientific Revolutions (Chicago: University of Chicago Press, 1962), and The Essential Tension (Chicago: University of Chicago Press, 1977).

2. The criterion of the fruitfulness of a research program, and issues connected with progressive versus degenerative problem shifts, were introduced by Imre Lakatos, "Falsification and the Methodology of Scientific Research Programmes," in Lakatos and Alan Musgrave, eds., Criticisms and the Growth of Knowledge (Cambridge: Cambridge University Press, 1970).

3. Edmund C. Mower, International Government (Boston: Heath, 1931). 
rary students of international organization would want to alter this definition substantially. ${ }^{4}$

However, there have been identifiable shifts in how the phenomenon of international governance has been conceived, especially since World War II-so much so that the field is often described as being in permanent search of its own "dependent variable." Our reading of the literature reveals four major analytical foci, which we would place in roughly the following logical-and more or less chronological-order.

\section{Formal institutions}

The first is a formal institutional focus. Within it, the assumption was made or the premise was implicit that (1) international governance is whatever international organizations do; and (2) the formal attributes of international organizations, such as their charters, voting procedures, committee structures, and the like, account for what they do. To the extent that the actual operation of institutions was explored, the frame of reference was their constitutional mandate, and the purpose of the exercise was to discover how closely it was approximated. ${ }^{5}$

\section{Institutional processes}

The second analytical focus concerns the actual decision-making processes within international organizations. The assumption was gradually abandoned that the formal arrangements of international organizations explain what they do. This perspective originally emerged in the attempt to come to grips with the increasingly obvious discrepancies between constitutional designs and organizational practices. Some writers argued that the formal arrangements and objectives remained relevant and appropriate but were undermined or obstructed by such political considerations as cold war rivalry and such institutional factors as the veto in the UN Security Council, bloc voting in the UN General Assembly, and the like. ${ }^{6}$ Others contended

4. The basic terms of the definition are entirely compatible with the most recent theoretical work in the field, Robert O. Keohane, After Hegemony (Princeton: Princeton University Press, 1984). The precise meaning of the terms of course has changed significantly, as we shall see presently.

5. A distinguished contribution to this literature is Leland M. Goodrich and Anne P. Simons, The United Nations and the Maintenance of International Peace and Security (Washington, D.C.: Brookings, 1955). See also Klaus Knorr, "The Bretton Woods Institutions in Transition," International Organization [hereafter cited as IO] 2 (February 1948); Walter R. Sharp. "The Institutional Framework for Technical Assistance," IO 7 (August 1953); and Henri Rolin, "The International Court of Justice and Domestic Jurisdiction," IO 8 (February 1954).

6. Norman J. Padelford, "The Use of the Veto," IO 2 (June 1948); Raymond Dennett, "Politics in the Security Council," IO 3 (August 1949); M. Margaret Ball, "Bloc Voting in the General Assembly," IO 5 (February 1951); Allan Hovey, Jr., "Obstructionism and the Rules of the General Assembly," IO 5 (August 1951); and Arlette Moldaver, "Repertoire of the Veto in the Security Council, 1946-1956," IO 11 (Spring 1957). 
that the original designs themselves were unrealistic and needed to be changed. ${ }^{7}$

Over time, this perspective became more generalized, to explore overall patterns of influence shaping organizational outcomes. ${ }^{8}$ The sources of influence which have been investigated include the power and prestige of individual states, the formation and functioning of the group system, organizational leadership positions, and bureaucratic politics. The outcomes that analysts have sought to explain have ranged from specific resolutions, programs, and budgets, to broader voting alignment and the general orientation of one or more international institutions.

\section{Organizational role}

In this third perspective, another assumption of the formal institutionalist approach was abandoned, namely, that international governance is whatever international organizations $d o$. Instead, the focus shifted to the actual and potential roles of international organizations in a more broadly conceived process of international governance. ${ }^{9}$ This perspective in turn subsumes three distinct clusters.

In the first cluster, the emphasis was on the roles of international organizations in the resolution of substantive international problems. Preventive diplomacy and peace-keeping were two such roles in the area of peace and security, ${ }^{10}$ nuclear safeguarding by the International Atomic Energy Agency (IAEA) was another. " Facilitating decolonization received a good deal of

7. See, among others, Sir Gladwyn Jebb, "The Role of the United Nations," IO 6 (November 1952); A. Loveday, "Suggestions for the Reform of UN Economic and Social Machinery," IO 7 (August 1953); Wytze Corter, "GATT after Six Years: An Appraisal," IO 8 (February 1954); Lawrence S. Finkelstein, "Reviewing the UN Charter," 109 (May 1955); Robert E. Riggs, "Overselling the UN Charter-Fact or Myth," IO 14 (Spring 1960); and Inis L. Claude, Jr., "The Management of Power in the Changing United Nations," $1 O 15$ (Spring 1961).

8. The most comprehensive work in this genre remains Robert W. Cox and Harold $\mathrm{K}$. Jacobson, eds., The Anatomy of Influence: Decision Making in International Organization (New Haven: Yale University Press, 1973).

9. Inis L. Claude's landmark text, Swords into Plowshares (New York: Random House, 1959), both signaled and contributed to this shift.

10. Lincoln P. Bloomfield, ed., International Force-A Symposium, IO 17 (Spring 1973); James M. Boyd, "Cyprus: Episode in Peacekeeping," IO 20 (Winter 1966); Robert O. Matthews, "The Suez Canal Dispute: A Case Study in Peaceful Settlement," IO 21 (Winter 1967); Yashpal Tandon, "Consensus and Authority behind UN Peacekeeping Operations," IO 21 (Spring 1967); David P. Forsythe, "United Nations Intervention in Conflict Situations Revisited: A Framework for Analysis," IO 23 (Winter 1969); John Gerard Ruggie, "Contingencies, Constraints, and Collective Security: Perspectives on UN Involvement in International Disputes," 1028 (Summer 1974); and Ernst B. Haas, "Regime Decay: Conflict Management and International Organization, 1945-1981," $1 O 37$ (Spring 1983).

11. Robert E. Pendley and Lawrence Scheinman, "International Safeguarding as Institutionalized Collective Behavior," in John Gerard Ruggie and Ernst B. Haas, eds., special issue on international responses to technology, IO 29 (Summer 1975); and Joseph S. Nye, "Maintaining a Non-Proliferation Regime," in George H. Quester, ed., special issue on nuclear nonproliferation, $1 O 35$ (Winter 1981). 
attention in the political realm, ${ }^{12}$ providing multilateral development assistance in the economic realm. ${ }^{13}$ The potential role of international organizations in restructuring North-South relations preoccupied a substantial number of scholars throughout the $1970 \mathrm{~s},{ }^{14}$ as did the possible contributions of international organizations to managing the so-called global commons. ${ }^{15}$ Most recently, analysts have challenged the presumption that the roles of international organizations in this regard are invariably positive; indeed, they have accused international organizations of occasionally exacerbating the problems they are designed to help resolve. ${ }^{16}$

The second cluster of the organizational-role perspective shifted the focus away from the solution of substantive problems per se, toward certain longterm institutional consequences of the failure to solve substantive problems through the available institutional means. This, of course, was the integrationist focus, particularly the neofunctionalist variety. ${ }^{17}$ It was fueled by the fact that the jurisdictional scope of both the state and existing international organizations was increasingly outstripped by the functional scope of international problems. And it sought to explore the extent to which institutional adaptations to this fact might be conducive to the emergence of political forms "beyond the nation state." 18 Neofunctionalists assigned a major role in this process to international organizations, not simply as passive recipients of new tasks and authority but as active agents of "task expansion" and

12. Ernst B. Haas, "The Attempt to Terminate Colonization: Acceptance of the UN Trusteeship System," 107 (February 1953); John Fletcher-Cooke, "Some Reflections on the International Trusteeship System," IO 13 (Summer 1959); Harold K. Jacobson, "The United Nations and Colonialism: A Tentative Appraisal," IO 16 (Winter 1962); and David A. Kay, "The Politics of Decolonization: The New Nations and the United Nations Political Process," IO 21 (Autumn 1967).

13. Richard N. Gardner and Max F. Millikan, eds., special issue on international agencies and economic development, $I O 22$ (Winter 1968).

14. Among many other sources, see Branislav Gosovic and John Gerard Ruggie, "On the Creation of a New International Economic Order: Issue Linkage and the Seventh Special Session of the UN General Assembly," $I O 30$ (Spring 1976).

15. David A. Kay and Eugene B. Skolnikoff, eds., special issue on international institutions and the environmental crisis, IO 26 (Spring 1972); Ruggie and Haas, eds., special issue, 1029 (Summer 1975); and Per Magnus Wijkman, "Managing the Global Commons," IO 36 (Summer 1982).

16. The most extreme form of this criticism recently has come from the political right in the United States; cf. Burton Yale Pines, ed., A World without the U.N.: What Would Happen If the United Nations Shut Down (Washington, D.C.: Heritage Foundation, 1984). But the same position has long been an article of faith on the political left as well; cf. Cheryl Payer, "The Perpetuation of Dependence: The IMF and the Third World," Monthly Review 23 (September 1971), and Payer, "The World Bank and the Small Farmers," Journal of Peace Research 16, no. 2 (1979); and the special issue of Development Dialogue, no. 2 (1980).

17. Various approaches to the study of integration were summarized and assessed in Leon $N$. Lindberg and Stuart A. Scheingold, eds., special issue on regional integration, IO 24 (Autumn 1970).

18. Ernst B. Haas, Beyond the Nation State: Functionalism and International Organization (Stanford: Stanford University Press, 1964). 
"spillover."19 Other approaches concerned themselves less with institutional changes than with attitudinal changes, whether among national elites, international delegates, or mass publics. ${ }^{20}$

The third cluster within the organizational-role perspective began with a critique of the transformational expectations of integration theory and then shifted the focus onto a more general concern with how international institutions "reflect and to some extent magnify or modify" the characteristic features of the international system. ${ }^{21}$ Here, international organizations have been viewed as potential dispensers of collective legitimacy, ${ }^{22}$ vehicles in the international politics of agenda formation, ${ }^{23}$ forums for the creation of transgovernmental coalitions as well as instruments of transgovernmental policy coordination, ${ }^{24}$ and as means through which the global dominance structure is enhanced or can possibly come to be undermined. ${ }^{25}$

The theme that unifies all works of this genre is that the process of global governance is not coterminous with the activities of international organiza-

19. In addition to Haas, ibid., see Philippe C. Schmitter, "Three Neo-Functionalist Hypotheses about International Integration," IO 23 (Winter 1969); Leon N. Lindberg and Stuart A. Scheingold, Europe's Would-Be Polity: Patterns of Change in the European Community (Englewood Cliffs, N.J.: Prentice-Hall, 1970); Joseph S. Nye, Peace in Parts: Integration and Conflict in Regional Organization (Boston: Little, Brown, 1971). For a critique of the neofunctionalist model, see Roger D. Hansen "Regional Integration: Reflection on a Decade of Theoretical Efforts," World Politics 21 (January 1969).

20. Henry H. Kerr, Jr., "Changing Attitudes through International Participation: European Parliamentarians and Integration," IO 27 (Winter 1973); Peter Wolf, "International Organizations and Attitude Change: A Re-examination of the Functionalist Approach," IO 27 (Summer 1973); David A. Karns, "The Effect of Interparliamentary Meetings on the Foreign Policy Attitudes of the United States Congressmen," IO 31 (Summer 1977); and Ronald Inglehart, "Public Opinion and Regional Integration," IO 24 (Autumn 1970).

21. The phrase is Stanley Hoffmann's in "International Organization and the International System," IO 24 (Summer 1970). A similar position was advanced earlier by Oran R. Young, "The United Nations and the International System," IO 22 (Autumn 1968).

22. Inis L. Claude, Jr., "Collective Legitimization as a Political Function of the United Nations," IO 20 (Summer 1966); cf. Jerome Slater, "The Limits of Legitimization in International Organizations: The Organization of American States and the Dominican Crisis," $1 O 23$ (Winter 1969).

23. A representative sampling would include Kay and Skolnikoff, eds., special issue, $I O 26$ (Spring 1972); Robert Russell, "Transgovernmental Interaction in the International Monetary System, 1960-1972," IO 27 (Autumn 1973); Thomas Weiss and Robert Jordan, "Bureaucratic Politics and the World Food Conference," World Politics 28 (April 1976); Raymond F. Hopkins, "The International Role of 'Domestic' Bureaucracy," IO 30 (Summer 1976); and John Gerard Ruggie, "On the Problem of 'The Global Problematique': What Roles for International Organizations?" Alternatives 5 (January 1980).

24. The major analytical piece initiating this genre was Robert $O$. Keohane and Joseph $S$. Nye, "Transgovernmental Relations and International Organizations," World Politics 27 (October 1974); cf. their earlier edited work on transnational relations and world politics, $1 O 25$ (Summer 1971).

25. Robert Cox's recent work has been at the forefront of exploring this aspect of international organization: "Labor and Hegemony," IO 31 (Summer 1977); "The Crisis of World Order and the Problem of International Organization in the 1980's," International Journal 35 (Spring 1980); and "Gramsci, Hegemony and International Relations: An Essay in Method," Millenium: Journal of International Studies 12 (Summer 1983). 
tions but that these organizations do play some role in that broader process. The objective was to identify their role.

\section{International regimes}

The current preoccupation in the field is with the phenomenon of international regimes. Regimes are broadly defined as governing arrangements constructed by states to coordinate their expectations and organize aspects of international behavior in various issue-areas. They thus comprise a normative element, state practice, and organizational roles. ${ }^{26}$ Examples include the trade regime, the monetary regime, the oceans regime, and others. The focus on regimes was a direct response both to the intellectual odyssey that we have just traced as well as to certain developments in the world of international relations from the 1970 s on.

When the presumed identity between international organizations and international governance was explicitly rejected, the precise roles of organizations in international governance became a central concern. But, apart from the focus on integration, no overarching conception was developed of international governance itself. And the integrationists themselves soon abandoned their early notions, ending up with a formulation of integration that did little more than recapitulate the condition of interdependence which was assumed to trigger integration in the first place. ${ }^{27}$ Thus, for a time the field of international organization lacked any systematic conception of its traditional analytical core: international governance. The introduction of the concept of regimes reflected an attempt to fill this void. International regimes were thought to express both the parameters and the perimeters of international governance. ${ }^{28}$

The impact of international affairs during the 1970s and beyond came in the form of an anomaly for which no ready-made explanation was at hand. Important changes occurred in the international system, associated with the relative decline of U.S. hegemony: the achievement of nuclear parity by the Soviet Union; the economic resurgence of Europe and Japan; the success of OPEC together with the severe international economic dislocations that followed it. Specific agreements that had been negotiated after World War II were violated, and institutional arrangements, in money and trade above all,

26. The most extensive analytical exploration of the concept may be found in Stephen D. Krasner, ed., International Regimes (Ithaca, N.Y.: Cornell University Press, 1983), most of which was first published as a special issue of $I O$ in Spring 1982. Page references will be to the book.

27. Robert O. Keohane and Joseph S. Nye, "International Interdependence and Integration," in Fred I. Greenstein and Nelson W. Polsby, eds., Handbook of Political Science, vol. 8 (Reading, Mass.: Addison-Wesley, 1975). The point is also implicit in Ernst Haas's selfcriticism, "Turbulent Fields and the Theory of Regional Integration," IO 30 (Spring 1976).

28. John Gerard Ruggie, "International Responses to Technology: Concepts and Trends," IO 29 (Summer 1975). 
came under enormous strain. Yet-and here is the anomaly-governments on the whole did not respond to the difficulties confronting them in beggarthy-neighbor terms. Neither systemic factors nor formal institutions alone apparently could account for this outcome. One way to resolve the anomaly was to question the extent to which U.S. hegemony in point of fact had eroded ${ }^{29}$ Another, and by no means entirely incompatible route, was via the concept of international regimes. The argument was advanced that regimes continued in some measure to constrain and condition the behavior of states toward one another, despite systemic change and institutional erosion. In this light, international regimes were seen to enjoy a degree of relative autonomy, though of an unknown duration. ${ }^{30}$

In sum, in order to resolve both disciplinary and real-world puzzles, the process of international governance has come to be associated with the concept of international regimes, occupying an ontological space somewhere between the level of formal institutions on the one hand and systemic factors on the other. Hence, the notion that the concern with international regimes is but another academic fad from which the field has suffered throughout the postwar period itself betrays a misunderstanding of the considerable intellectual continuity that has brought the field to the present point. ${ }^{31}$

These shifts in analytical foci of course have never been complete; not everyone in the field at any one time works within the same perspective, and once introduced into the field no perspective ever disappears altogether. To provide some sense of relative orders of magnitude and of changes in them over time, a brief review of all articles ever published in $I O$ may be of help. Figure 1 summarizes their analytical foci, defined as they are in the text, except that "international integration" as a focus has been separated out from the more general category of "organizational roles" in order to highlight a particular evolutionary pattern.

Two trends are striking. First, the formal institutional focus has declined steadily from the very beginning and now accounts for fewer than 5 percent of the total. Second, the category of "general international relations" has dominated every other from the mid-1960s on and now accounts for over 60 percent of the total. A comprehensive sociology of knowledge, not only of the field but also of the journal, would be required to explain fully this latter

29. This is the tack taken by Susan Strange, "Still an Extraordinary Power: America's Role in a Global Monetary System," in Raymond E. Lombra and William E. Witte, eds., Political Economy of International and Domestic Monetary Relations (Ames: lowa State University Press, 1982); and Bruce Russett, "The Mysterious Case of Vanishing Hegemony: Or, Is Mark Twain Really Dead?" 1039 (Spring 1985).

30. See Krasner, "Introduction," International Regimes, and Keohane, After Hegemony, for discussions of this thesis.

31. The fad-fettish is argued by Susan Strange, "Cave! Hic Dragones: A Critique of Regime Analysis," in Krasner, ed., International Regimes. 


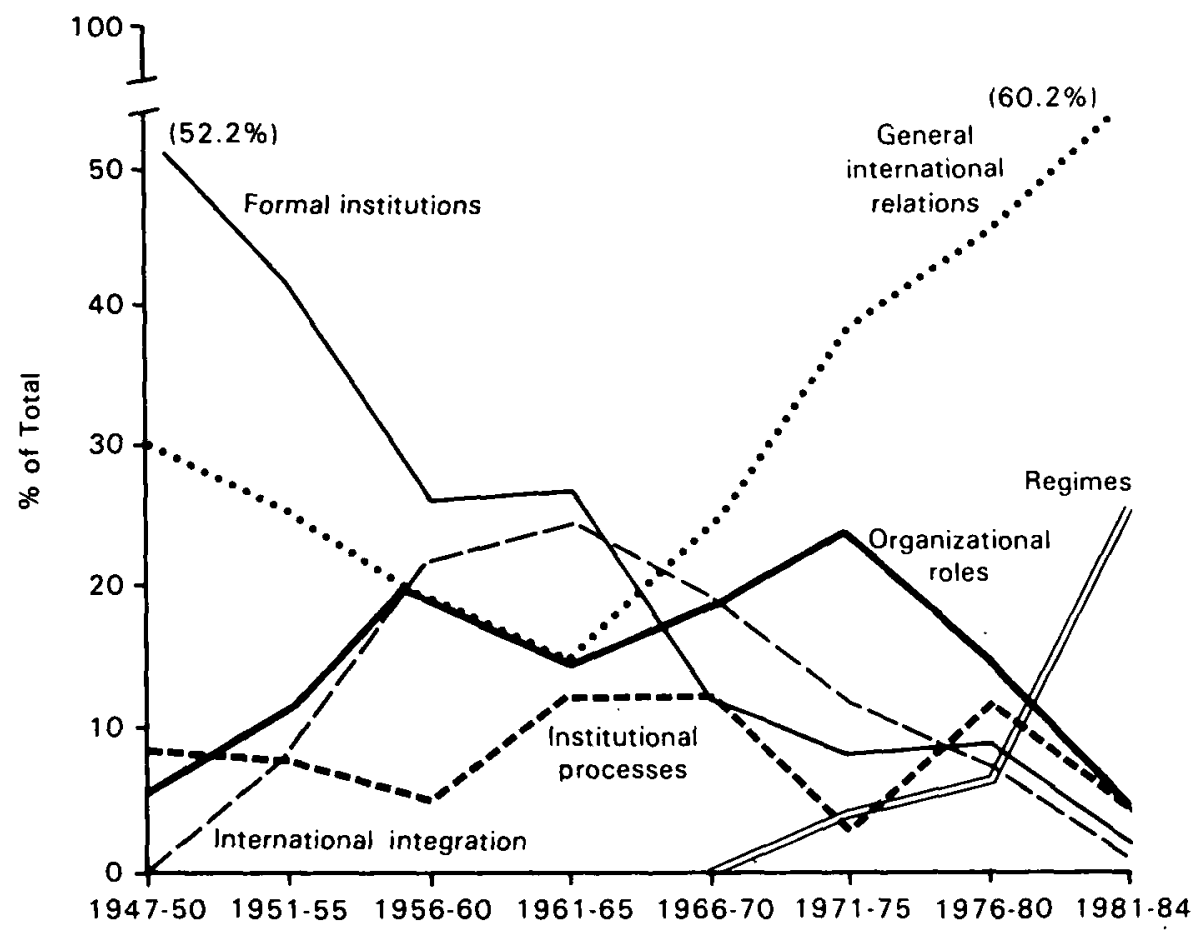

FIGURE 1. Analytical foci of contributions to International Organization.

Source. International Organization, 1947-84.

trend. But in part at least it reflects the loss of an analytical core of which we spoke above, which the concept of regimes was designed to provide. As Figure 1 also shows, the focus on regimes emerged suddenly in the 1970s and now ranks in second place.

In addition, there exists an interesting relationship between studies of organizational roles, international integration, and regimes. The first phase of organizational-role studies, it will be recalled, had a substantive focus, namely the contributions of international organizations to resolving the various problems confronting the international community. It was overtaken by integration studies by 1960 , the concern of which was the impact of international organizations not on solving the substance but on changing the process of international governance. When integration studies declined about ten years later, they were overtaken in turn by studies that rejected the specific focus on integration as an outcome but continued to concern themselves with the role of organizations in the general process of international governance. And the decline of this latter phase of organizational-role studies clearly coincides with the emergence of regime studies, suggesting a fairly direct lineage. 


\section{Conflict and cooperation}

These shifts in analytical foci have been accompanied by an analytical shift of a very different sort, perhaps most clearly expressed in the premises of recent methodological approaches. Take the rational-choice approach as one instance. ${ }^{32}$ It raises the promise and offers the possibility that two strands of thinking about international relations which have been distinct if not oppositional in the past may become unified. Typically, the opposition has been expressed in the conflict/cooperation dichotomy. It has been widely assumed throughout the history of modern international relations theory that there exists one realm of international life which is intrinsically conflictual and another which is intrinsically more cooperative. Moreover, it has been inferred from this premise that these two realms of international life require (from the vantage point of conflict studies) or make possible (from the vantage point of cooperation studies) two very different modes of analysis. Realism and to a lesser extent Marxism have tended to dominate the former strand, and liberalism in its many guises-Ricardian trade theory, Wilsonian idealism, functionalism, and interdependence imperatives-the latter.

What we find in the recent literature inspired by the rational-choice perspective, on the contrary, is the claim that both conflict and cooperation can be explained by a single logical apparatus. ${ }^{33}$ Moreover, the differences between the two branches now are understood to reflect situational determinants not structural determinants. In game-theoretic terms, such situational factors include how many rounds are played in a game resembling an iterated Prisoner's Dilemma, how much the value of future payoffs is discounted in comparison with immediate payoffs, whether or not swift and decisive defection from cooperation is possible, and so on. ${ }^{34}$ Interestingly, developments in some neo-Marxist approaches have proceeded on precisely

32. The public-choice approach to the study of international organization began with the use of public goods theory in the early 1970s, went on to explore the theory of property rights later in the decade, and has come to focus on game theory and microeconomic theories of market failure to explain patterns of international governance. See, respectively, Bruce M. Russett and John D. Sullivan, "Collective Goods and International Organizations," IO 25 (Autumn 1971), and John Gerard Ruggie, "Collective Goods and Future International Collaboration," American Political Science Review 66 (September 1972); John A. C. Conybeare, "International Organization and the Theory of Property Rights," IO 34 (Summer 1980); and Keohane, After Hegemony. A useful review of the relevant literature may be found in Bruno S. Frey, "The Public Choice View of International Political Economy," IO 38 (Winter 1984).

33. In the context of rational-choice theory generally, the argument was first articulated by John Harsanyi, "Rational Choice Models of Political Behavior vs. Functionalist and Conformist Theories," World Politics 21 (July 1969). In the international relations literature, it is implicit in Robert Jervis, "Cooperation under the Security Dilemma," World Politics 30 (January 1978), and explicit in Robert Axelrod, "The Emergence of Cooperation among Egoists," American Political Science Review 75 (June 1981), as well as in Keohane, After Hegemony.

34. Robert Jervis first made these points in his paper "Security Regimes," in Krasner, ed., International Regimes. For a more extended discussion see Charles Lipson, "International Cooperation in Economic and Security Affairs," World Politics 37 (October 1984). 
analogous lines, insofar as the traditional opposites, unity and rivalry, have been collapsed within a single "world system" framework, or insofar as the question of unity versus rivalry has been derived from the presence or absence of "hegemony" in the Gramscian sense of the term. ${ }^{35}$ Approaches informed by hermeneutics and language philosophy are reaching much the same conclusions as well. ${ }^{36}$ And in each case, the concept of regimes is found to be a useful focal point for analysis.

In summary, that branch of the study of international relations which calls itself international organization is lively and productive. It is once again focusing squarely on the phenomenon of international governance, and it is pursuing its object of study in innovative ways that are bringing it closer to the theoretical core of more general international relations work. These are no mean accomplishments. And they are not diminished by the fact that serious problems remain to be resolved.

\section{Problems in the practice of regime analysis}

One of the major criticisms made of the regimes concept is its "wooliness" and "imprecision." 37 The point is well taken. There is no agreement in the literature even on such basic issues as boundary conditions: Where does one regime end and another begin? What is the threshold between nonregime and regime? Embedding regimes in "meta-regimes," or "nesting" one within another, typifies the problem; it does not resolve it. ${ }^{38}$ The same is true of the proposal that any set of patterned or conventionalized behavior be considered as prima facie evidence for the existence of a regime. ${ }^{39}$

The only cure for wooliness and imprecision is, of course, to make the concept of regimes less so. Definitions can still be refined, but only up to a point. Two fundamental impediments stand in the way. One is absolute: ultimately, there exists no external Archimedian point from which regimes can be viewed as they "truly" are. This is so because regimes are conceptual creations not concrete entities. As with any analytical construction in the human sciences, the concept of regimes will reflect commonsense understandings, actor preferences, and the particular purposes for which analyses

35. Immanuel Wallerstein, "The Rise and Future Demise of the World Capitalist System: Concepts for Comparative Analysis," Comparative Studies in Society and History 16 (September 1974); and Cox, "Labor and Hegemony," "The Crisis of World Order," and "Gramsci, Hegemony, and International Relations."

36. Richard K. Ashley, "The Poverty of Neorealism," IO 38 (Spring 1984), and Friedrich Kratochwil, "Errors Have Their Advantage," IO 38 (Spring 1984).

37. See Susan Strange, in Krasner, ed., International Regimes.

38. This route is taken by Vinod K. Aggarwal, Liberal Protectionism: The International Politics of Organized Textile Trade (Berkeley: University of California Press, 1985).

39. Oran R. Young, "Regime Dynamics: The Rise and Fall of International Regimes," in Krasner, ed., International Regimes. 
are undertaken. Ultimately, therefore, the concept of regimes, like the concept of "power," or "state," or "revolution," will remain a "contestable concept. "40

Well short of this absolute impediment stands another. It is not insuperable, but a great deal of work will have to be done in order to overcome it. The problem is this: the practice of regime analysis is wracked by epistemological anomalies-anomalies that more often than not go unnoticed in the literature. These anomalies debilitate any endeavor to achieve clarity and precision in the concept of regimes and to enhance its productive capacity as an analytical tool. In the paragraphs that follow, we flag three related epistemological problem areas. Without pretending that we can resolve them here, we hope merely to obtain their entry into the disciplinary discourse.

\section{Ontology versus epistemology}

International regimes are commonly defined as social institutions around which expectations converge in international issue-areas. The emphasis on convergent expectations as the constitutive basis of regimes gives regimes an inescapable intersubjective quality. It follows that we know regimes by their principled and shared understandings of desirable and acceptable forms of social behavior. Hence, the ontology of regimes rests upon a strong element of intersubjectivity.

Now, consider the fact that the prevailing epistemological position in regime analysis is almost entirely positivistic in orientation. Before it does anything else, positivism posits a radical separation of subject and object. It then focuses on the "objective" forces that move actors in their social interactions. Finally, intersubjective meaning, where it is considered at all, is inferred from behavior.

Here, then, we have the most debilitating problem of all: epistemology fundamentally contradicts ontology! Small wonder that so much disagreement exists on what should be fairly straightforward empirical questions: Did Bretton Woods "collapse" in 1971-73, or was the change "norm governed"? Are recent trade restraints indicative of dangerous protectionism or not? How is it that the Non-Proliferation Treaty in 1985 successfully passed yet another review, when so many states that voluntarily adhere to it protest its inequitable terms? And on and on.

In many such puzzling instances, actor behavior has failed adequately to convey intersubjective meaning. And intersubjective meaning, in turn, seems to have had considerable influence on actor behavior. It is precisely this factor that limits the practical utility of the otherwise fascinating insights into the collaborative potential of rational egoists which are derived from

40. On "contestable concepts," see William Connally, The Terms of Political Discourse, 2d ed. (Princeton: Princeton University Press, 1983). 
laboratory or game-theoretic situations. ${ }^{41}$ To put the problem in its simplest terms: in the simulated world, actors cannot communicate and engage in behavior; they are condemned to communicate through behavior. In the real world, the situation of course differs fundamentally. Here, the very essence of international regimes is expressed in cases such as that of France in 1968, asking for "sympathy and understanding" from its trading partners, as France invoked emergency measures against imports after the May disturbances of that year-and getting both from GATT (General Agreement on Tariffs and Trade) even though no objective basis existed in fact or in GATT law for doing so. But a positivist epistemology simply cannot accommodate itself to so intersubjective an ontology. Hence, the case is treated in the literature as illustrating cynicism, complicity, and the erosion of respect for the GATT regime. ${ }^{42}$

The contradiction between ontology and epistemology has elicited surprisingly little concern in the regimes literature. ${ }^{43}$ Once it is realized just how problematical the contradiction is, however, what options exist to deal with it? One possibility would be to try to deny it somehow. Theodore Abel's classic neopositivist response to the challenge posed by Weber's concept of Verstehen might serve as a model: the concept aids in "the context discovery," Abel contended, but ultimately it is not a method relevant to "the context of validation." Hence it poses no challenge. ${ }^{44}$ This response may have been viable a generation ago, but it no longer is. Interpretive epistemologies that stress the intimate relationship between validation and the uncovering of intersubjective meanings are simply too well developed today to be easily dismissed by charges of subjectivism ${ }^{45}$-or, more likely in the arena of international relations theory, of idealism.

41. Most notable among such works is Robert Axelrod's Evolution of Cooperation (New York: Basic, 1984), and Axelrod, "Modeling the Evolution of Norms" (Paper delivered at the annual meeting of the American Political Science Association, New Orleans, 29 August-1 September 1985). For an attempt to incorporate progressively more "reflective" logical procedures into sequential Prisoner's Dilemma situations and to expose them to more realistic data sets, see Hayward R. Alker, James Bennett, and Dwain Mefford, "Generalized Precedent Logics for Resolving Insecurity Dilemmas," International Interactions 7, no. 2 (1980), and Hayward Alker and Akihiro Tanaka, "Resolution Possibilities in 'Historical' Prisoners' Dilemmas" (Paper delivered at the annual meeting of the International Studies Association, Philadelphia, 18 March 1981).

42. This case, and the more general problem of interpretation which it reflects, are discussed by John Gerard Ruggie, "International Regimes, Transactions, and Change: Embedded Liberalism in the Postwar Economic Order," in Krasner, ed., International Regimes.

43. In the basic regime text, International Regimes, edited by Krasner, intersubjectivity is stressed by Ruggie, "Embedded Liberalism," and by Donald J. Puchala and Raymond F. Hopkins, "International Regimes: Lessons from Inductive Analysis," but no systematic epistemological discussion is undertaken in the volume.

44. Theodore F. Abel, "The Operation Called Verstehen," American Journal of Sociology 54 (November 1948).

45. For a good selection of readings that begins with Weber, includes the neopositivist response, the Wittgensteinian school, phenomenology, and ethnomethodology, and ends with hermeneutics and critical theory, see Fred R. Dallmayr and Thomas A. McCarthy, Understanding and Social Inquiry (Notre Dame: University of Notre Dame Press, 1977). 
A second possibility would be to try to formulate a rendition of the intersubjective ontology which is compatible with positivist epistemology. In view of the influence currently enjoyed in international relations theory by analogies and metaphors drawn from microeconomics, one plausible means of executing this maneuver would be to follow the economists down the road of "revealed preferences" - that consumption behavior, for example, reveals true consumer preferences. If our epistemology does not enable us to uncover meaning, the analogous reasoning would hold, then let us look for "revealed meaning," that is, for "objective" surrogates. It should suffice to point out that this is a solution by displacement: it displaces the problem into the realm of assumption-namely that "objective" surrogates can capture "intersubjective" reality-which of course is not uncharacteristic of the manner in which economists handle difficult problems.

That leaves us with the third and only viable option, of opening up the positivist epistemology to more interpretive strains, more closely attuned to the reality of regimes. Experimentation along these lines has begun. Ernst Haas has been moving steadily toward his own brand of an "evolutionary epistemology," wherein consensual knowledge about various aspects of the human condition becomes one of the forces behind the rise and decline of international regimes. ${ }^{46}$ Robert Cox has advanced an unconventional historical materialist epistemology, which gives pride of place to shifting intersubjective frameworks of human discourse and practice. ${ }^{47}$ Epistemological positions derived from the "universal pragmatics" of Jürgen Habermas, or informed by the "interpretive analytics" of Michel Foucault, have been found fruitful. ${ }^{48}$ Other possibilities have been probed as well. ${ }^{49}$ The burden of our discussion is not to advocate any one such alternative but to urge that their consideration be delayed no longer.

\section{Norms in explanation}

There is a closely related problem having to do with models of explanation. The standard positivist model works with an initial condition plus a

46. The position is signaled in Ernst B. Haas, "Words Can Hurt You; Or, Who Said What to Whom about Regimes," in Krasner, ed., International Regimes; and elaborated in Haas, "What Is Progress in the Study of International Organization?" which has been published only in Japanese translation.

47. Robert W. Cox, "Social Forces, States, and World Orders: Beyond International Relations Theory," and, especially, "Postscript 1985," both in Robert O. Keohane, ed., Neorealism and Its Critics (New York: Columbia University Press, 1986).

48. See, respectively, Friedrich Kratochwil, "Rules, Norms, and Decisions: On the Conditions of Practical and Legal Reasoning in International Relations" (Manuscript, Columbia University, 1986); and John Gerard Ruggie, Planetary Politics: Ecology and the Organization of Global Political Space (New York: Columbia University Press, forthcoming).

49. For example, a nondeterministic dialectical formulation of states' conceptions of world order is sketched out by Hayward R. Alker, "Dialectical Foundations of Global Disparities," International Studies Quarterly 25 (March 1981); and of the mutual recognition among states of competencies to act in collectively prescribed ways, by Richard Ashley, "Poverty of Neorealism." 
covering law, on the basis of which it hypothesizes or predicts an occurrence. Even a single counterfactual occurrence may be taken to refute the covering law..$^{50}$ (A probabilistic formulation would, of course, appropriately modify the criteria for refutation, but it would not alter the basic structure of the explanation.)

Now consider the fact that what distinguishes international regimes from other international phenomena-from strategic interaction, let us say-is a specifically normative element. ${ }^{51}$ Indeed, one of the four analytical components of the concept of regimes is specified to be norms-" "standards of behavior defined in terms of rights and obligations." And it has become customary to maintain that change in the normative structure of regimes produces change of, as opposed merely to within, regimes. ${ }^{52}$

The positivist model of explanation is not easily applied to cases in which norms, so defined, are a significant element in the phenomena to be explained. Alas, the positivist model reigns in regime analysis. Two problems in particular need to be raised. ${ }^{53}$

First, unlike the initial conditions in positivist explanations, norms can be thought of only with great difficulty as "causing" occurrences. Norms may "guide" behavior, they may "inspire" behavior, they may "rationalize" or "justify" behavior, they may express "mutual expectations" about behavior, or they may be ignored. But they do not effect cause in the sense that a bullet through the heart causes death or an uncontrolled surge in the money supply causes price inflation. Hence, where norms are involved, the first component of the positivist model of explanation is problematical.

The second is even more so. For norms are counterfactually valid. No single counterfactual occurrence refutes a norm. Not even many such occurrences necessarily do. Does driving while under the influence of alcohol refute the law (norm) against drunk driving? Does it when half the population is implicated? To be sure, the law (norm) is violated thereby. But whether or not violations also invalidate or refute a law (norm) will depend upon a host of other factors, not the least of which is how the community assesses the violation and responds to it. What is true of drunk driving is

50. On the importance of the logical form of modus tollens in the hypothetical deductive explanation scheme, see Karl Popper, The Logic of Scientific Discovery (New York: Harper \& Row, 1968), chaps. 3 and 4.

51. One of the distinctive characteristics of strategic interaction is that ultimately it rests upon a unilateral calculation of verbal and nonverbal cues: "A's expectation of $B$ will include an estimation of B's expectations of A. This process of replication, it must be noted, is not an interaction between two states, but rather a process in which decision-makers in one state work out the consequences of their beliefs about the world; a world they believe to include decisionmakers in other states, also working out the consequences of their beliefs. The expectations which are so formed are the expectations of one state, but they refer to other states." Paul Keal, Unspoken Rules and Superpower Dominance (London: Macmillan, 1984), p. 31.

52. See Krasner, "Introduction," International Regimes.

53. Some of these and related issues are discussed more extensively in Kratochwil, "The Force of Prescriptions," IO 38 (Autumn 1984). 
equally true of the norms of nondiscrimination in international trade, free and stable currency exchanges, and adequate compensation for expropriated foreign property.

Indeed, it is possible to go further and argue that norms need not "exist" at all in a formal sense in order to be valid. It is often said, for example, that the Bretton Woods monetary regime did not exist prior to 1958 , because only then did the Europeans assume the obligation of full currency convertibility for transactions on current account. But surely the norms of the regime guided the behavior of European states toward that event for some years before it actually took place. Thus, neither the violation of norms, nor, in some special circumstances, even their "nonexistence," necessarily refutes their validity.

Let it be understood that we are not advocating a coup whereby the reign of positivist explanation is replaced by explanatory anarchy. But we would insist that, just as epistemology has to match ontology, so too does the explanatory model have to be compatible with the basic nature of the particular scientific enterprise at hand. The impact of norms within international regimes is not a passive process, which can be ascertained analogously to that of Newtonian laws governing the collision of two bodies. Hence, the common practice of treating norms as "variables"-be they independent, dependent, intervening, or otherwise-should be severely curtailed. So too should be the preoccupation with the "violation" of norms as the beginning, middle, and end of the compliance story. Precisely because state behavior within regimes is interpreted by other states, the rationales and justifications for behavior which are proffered, together with pleas for understanding or admissions of guilt, as well as the responsiveness to such reasoning on the part of other states, all are absolutely critical component parts of any explanation involving the efficacy of norms. Indeed, such communicative dynamics may tell us far more about how robust a regime is than overt behavior alone. And only where noncompliance is widespread, persistent, and unexcused-that is, presumably, in limiting cases-will an explanatory model that rests on overt behavior alone suffice. ${ }^{54}$

To be sure, communicative dynamics may be influenced by such extracontextual factors as state power, but that is no warrant for ignoring them. On the contrary, it suggests a potentially important relationship to be explored. ${ }^{55}$ Similarly, the fact that verbal behavior may lend itself to manipula-

54. Account should also be taken of that fact that different types of norms-implicit versus explicit, constraining versus enabling, and so on-function differently in social relations. Consult Edna Ullman-Margalit, The Emergence of Norms (Oxford: Clarendon, 1977), and H. L. A. Hart, The Concept of Law (Oxford: Oxford University Press, 1961). Moreover, compliance too is a variegated and complex phenomenon, as discussed by Oran R. Young, Compliance and Public Authority (Baltimore: Johns Hopkins University Press, 1979).

55. It is well established that the so-called hegemonic stability thesis, for example, leaves a good deal about regimes still to be accounted for. See the original formulation and test by 
tion suggests only that it be treated as judiciously as any other piece of scientific evidence.

\section{The hierarchy of analytical components}

The concept of international regimes is said to be a composite of four analytical component parts: principles ("beliefs of fact, causation, and rectitude"), norms ("standards of behavior defined in terms of rights and obligations"), rules ("specific prescriptions and proscriptions for action"), and decision-making procedures ("prevailing practices for making and implementing collective choice"). ${ }^{56}$ At first blush, the four fit together neatly in the specific case that was uppermost in everyone's mind when this conception was initially hammered out: the GATT-based trade regime. ${ }^{57}$ The principle that liberalized trade is good for global welfare and international peace was readily translated by states into such norms as nondiscrimination, which in turn suggested the most-favored-nation rule, all of which led to negotiated tariff reductions based on reciprocal concessions. But matters were complicated right from the start by the fact that GA'TT contained not one but at least two such "scripts," and that the second stood in stark contrast to the first. The second ran from the responsibility of governments to stabilize their domestic economies on through the norm of safeguarding the balance of payments and, under certain circumstances, domestic producers, to rules defining specific GATT safeguarding provisions, and finally to establishing mechanisms of multilateral surveillance over their operations. ${ }^{58}$ Different governments of course weighted these two scripts differently, but over time they seem not to have been unduly perturbed by the need to live with the ambiguity of their juxtaposition. Ambiguity, however, is more troublesome

Robert O. Keohane, "Theory of Hegemonic Stability and Changes in International Economic Regimes," in Ole Holsti et al., eds., Change in the International System (Boulder: Westview, 1980); and, most recently, Duncan Snidal, "The Limits of Hegemonic Stability Theory," IO 39 (Autumn 1985). One of the few contemporary realists who take the relationship between power and norms to be at all problematical and worthy of serious examination is Stephen D. Krasner, as in his thoughtful study of these issues in Structural Conflict: The Third World against Global Liberalism (Berkeley: University of California Press, 1985). We can agree with much of what Krasner has to say about the efficacy of norms, principles of legitimacy, and "movements of thought" -indeed, Krasner even invokes hermeneutics. And yet, in the end, we remain perplexed at how he reconciles this position with his fervent commitment to positivist realism.

56. Krasner, "Introduction," International Regimes, p. 2.

57. These issues were discussed at length at the October 1980 UCLA conference in preparation for the regimes book edited by Krasner.

58. The interplay between these two scripts forms the basis of Buggie's interpretation of the postwar trade and monetary regimes presented in "Embedded Liberalism." 
for analysts, even when it is a deliberate creation of policy makers. ${ }^{59}$ And therein lies another epistemological tale.

The notion still prevails in the regimes literature that the four analytical components are related instrumentally and that the greater the coherence among them is, the stronger the regime will be ${ }^{60}$ There is an a priori attractiveness to this notion, in the sense that our collective research program would be eased considerably were it to obtain. But reality is not so obliging. Let us take up first the instrumentalist idea.

A basic epistemological problem with instrumentalism is its presumption that it is always possible to separate goals (presumably expressed in principles and norms) from means (presumably expressed in rules and procedures), and to order them in a superordinate-subordinate relationship. But this relationship need not hold. As R. S. Summers has aptly remarked: "However true this might be of constructing houses or other artifacts, it is not always so in law. In law when available means limit and in part define the goal, the means and the goal thus defined are to that extent inseparable." What is true of law may also be true of regimes, for, as Kenneth Waltz has argued persuasively, international collaboration is shaped primarily by the availability and acceptability of means not by the desirability of ends. ${ }^{62}$ Thus, notions such as reciprocity in the trade regime are neither its ends nor its means: in a quintessential way, they are the regime-they are the principled and shared understandings that the regime comprises.

The idea that the four regime components should also be coherent, and that coherence indicates regime strength, is even more profoundly problematical. The basic epistemological problem with this notion is its presumption that, once the machinery is in place, actors merely remain programmed by it. But this is clearly not so. Actors not only reproduce normative structures, they also change them by their very practice, as underlying conditions change, as new constraints or possibilities emerge, or as new claimants make their presence felt. Lawyers call this "interstitial lawmaking,"63 and sociologists, the process of "structuration." 64 Only under

59. The proclivity of international relations theorists to resolve ambiguity and contradiction in images of international order, and the schema on the basis of which they do so, are explored by John Gerard Ruggie, "Changing Frameworks of International Collective Behavior: On the Complementarity of Contradictory Tendencies," in Nazli Choucri and Thomas Robinson, eds., Forecasting in International Relations (San Francisco: Freeman, 1978).

60. Cf. Haas, "Regime Decay."

61. R. S. Summers, "Naive Instrumentalism and the Law," in P. S. Hacker and J. Raz, eds., Law, Morality, and Society (Oxford: Clarendon, 1977).

62. Kenneth N. Waltz, Theory of International Politics (Reading, Mass.: Addison-Wesley, 1979), p. 109.

63. This is simply another name for the role of precedent in legal interpretation and development.

64. Anthony Giddens, A Contemporary Critique of Historical Materialism (Berkeley: University of California Press, 1981), p. 19: "According to the theory of structuration, all social action consists of social practices, situated in time-space, and organized in a skilled and knowl- 
extremely unusual circumstances could we imagine parallel and simultaneous changes having taken place in each of the four component parts of regimes such that they remained coherent-assuming that they were so at the outset. In any case the robustness of international regimes has little to do with how coherent they remain-how coherent is the very robust U.S. Constitution?-but depends on the extent to which evolving and even diverging practices of actors express principled reasoning and shared understandings.

We have now reached the same conclusion through three different routes: the conventional epistemological approaches in regime studies do not and cannot suffice. Allow us, before ending this section, to resist the claim that we have opened up a proverbial Pandora's box. The box was opened when the discipline gravitated toward an intersubjective ontology in the study of international regimes. We have merely pointed out that this first, critical choice has consequences and implications that have not yet been adequately addressed. No discipline can resolve anomalies or reduce the wooliness of concepts when its ontological posture is contradicted by its epistemological orientation, models of explanation, and the presumed relationships among its constitutive analytical constructs. The problems we have pointed to are not insuperable, but their resolution will require the incorporation into prevailing approaches of insights and methods derived from the interpretive sciences. ${ }^{65}$

\section{Regimes and organizations}

The progressive shift in the literature toward the study of international regimes has been guided by an abiding concern with the structures and processes of international governance. Despite remaining problems with this framework of analysis, the most serious of which were flagged in the previous section, a great deal has been accomplished in a relatively short span of time. Along the way, however, as Figure 1 indicated, international institutions of a formal kind have been left behind. This fact is of academic interest because of the ever-present danger of theory getting out of touch with prac-

edgeable fashion by human agents. But such knowledgeability is always 'bounded' by unacknowledged conditions of action on the one side, and unintended consequences of action on the other.... By the duality of structure I mean that the structured properties of social systems are simultaneously the medium and outcome of social acts."

65. Representative approaches may be found in Richard Bernstein, Praxis and Action (Philadelphia: University of Pennsylvania Press, 1971); Stephen Toulmin, Human Understanding (Princeton: Princeton University Press, 1972); Clifford Geertz, The Interpretation of Cultures (New York: Basic, 1973); Paul Connerton, Critical Sociology (New York: Penguin, 1976); Dallmayr and McCarthy, Social Inquiry; T. K. Seung, Structuralism and Hermeneutics (New York: Columbia University Press, 1982); Donald Polkinghorne, Methodology of the Human Sciences (Albany: State University of New York Press, 1983); and Hubert L. Dreyfus and Paul Rabinow, Michel Foucault: Beyond Structuralism and Hermeneutics (Chicago: University of Chicago Press, 1983). 
tice. But it is also of more than academic interest. The secretary general of the United Nations, to cite but one serious practical instance, has lamented that the malfunctioning of that institution seriously inhibits interstate collaboration in the peace and security field. ${ }^{66}$ This is not the place to take up detailed institutional shortcomings in the world of international organizations. Nor would we be the ones to propose a return to the institutionalist approaches of yesteryear. Nevertheless, in order for the research program of international regimes both to contribute to ongoing policy concerns and better reflect the complex and sometimes ambiguous policy realm, it is necessary to link up regimes in some fashion with the formal mechanisms through which real-world actors operate. In point of fact, the outlines of such linkages are already implicit in the regime approach. Our purpose in this final section is no more than to underscore the specific dimensions that are highlighted by an interpretive epistemology.

There has been a great deal of interest in the regimes literature recently in what can be described as the "organizational-design" approach. The key issue underlying this approach is to discern what range of international policy problems can best be handled by different kinds of institutional arrangements, such as simple norms of coordination, the reallocation of international property rights, or authoritative control through formal organizations. For example, an international fishing authority would probably be less appropriate and less able to avoid the early exhaustion of fisheries' stock than would the ascription of exclusive property rights to states. Where problems of liability enter the picture, however, as in ship-based pollution, authoritative procedures for settling disputes would become necessary. The work of Oliver Williamson and William Ouchi is very suggestive here, demonstrating the relative efficacy of the institutionalization of behavior through "hierarchies" versus through transaction-based informal means. ${ }^{67}$ Robert Keohane has pioneered this territory in his "functional" theory of international regimes, from which organizational designs can be similarly derived. ${ }^{68}$

For its part, an interpretive epistemology would emphasize three additional dimensions of the organizational-design issue. The intersubjective

66. United Nations, Report of the Secretary-General on the Work of the Organization, 1982 $(\mathrm{A} / 37 / 1)$.

67. Oliver Williamson, Markets and Hierarchies (New York: Free, 1975), and William Ouchi and Oliver Williamson, "The Markets and Hierarchies Program of Research: Origins, Implications, Prospects," in William Joyce and Andrew van de Ven, eds., Organization Design (New York: Wiley, 1981). From the legal literature, see Guido Calabresi and Douglas Melamed, "Property Rules, Liability Rules, and Inalienability: One View of the Cathedral," Harvard Law Review 85 (April 1972); Philip Heyemann, "The Problem of Coordination: Bargaining with Rules," Harvard Law Review 86 (March 1973); and Susan Rose-Ackerman, "Inalienability and the Theory of Property Rights," Columbia Law Review 8.5 (June 1985).

68. Keohane, After Hegemony. Some policy recommendations that flow from the approach are spelled out by Robert O. Keohane and Joseph S. Nye, "Two Cheers for Multilateralism," Foreign Policy 60 (Fall 1985). 
basis of international regimes suggests that transparency of actor behavior and expectations within regimes is one of their core requirements. And, as has been shown in such diverse issue-areas as international trade, investment, nuclear nonproliferation, and human rights, international organizations can be particularly effective instruments by which to create such transparency. ${ }^{69}$ The appropriate design of the mechanisms by which international organizations do so, therefore, should be given every bit as much consideration as the design of the mechanisms of substantive problem solving.

The second is legitimation. A regime can be perfectly rationally designed but erode because its legitimacy is undermined.$^{70}$ Or a regime that is a logical nonstarter can be the object of endless negotiations because a significant constituency views its aims to be legitimate. ${ }^{71}$ If a regime enjoys both it is described as being "stable" or "hegemonic." The important point to note is that international organizations, because of their trappings of universality, are the major venue within which the global legitimation struggle over international regimes is carried out today. Work in this genre goes back at least to Inis Claude and includes important recent contributions by Robert Cox and Stephen Krasner. ${ }^{72}$

The third dimension we would describe as epistemic. Stephen Toulmin has posed the issue well: "The problem of human understanding is a twofold one. Man knows, and he is also conscious that he knows. We acquire, possess, and make use of our knowledge; but at the same time, we are aware of our own activities as knowers." processes whereby knowledge becomes more extensive nor the means whereby reflection on knowledge deepens are passive or automatic. They are intensely political. And for better or for worse, international organizations have maneuvered themselves into the position of being the vehicle through which both types of knowledge enter onto the international agenda. ${ }^{74}$ As Ernst Haas has sought to show in his seminal work, in these

69. The GATT multilateral surveillance mechanisms are, of course, its chief institutional means of establishing intersubjectively acceptable interpretations of what actors are up to. For a treatment of investment which highlights this dimension, see Charles Lipson, Standing Guard: Protecting Foreign Capital in the Nineteenth and Twentieth Centuries (Berkeley: University of California Press, 1985); for nonproliferation, see Nye, "Maintaining a Nonproliferation Regime," and for human rights, John Gerard Ruggie, "Human Rights and the Future International Community Daedalus 112 (Fall 1983). The impact of intergovernmental information systems is analyzed by Ernst B. Haas and John Gerard Ruggie, "What Message in the Medium of Information Systems?" International Studies Quarterly 26 (June 1982).

70. Puchala and Hopkins, "International Regimes," in Krasner, ed., International Regimes, discuss the decline of colonialism in terms that include this dimension.

71. The New International Economic Order is a prime example.

72. See Claude, "Collective Legitimization"; Cox, "Labor and Hegemony," "The Crisis of World Order," and "Gramsci, Hegemony, and International Relations"; and Krasner, Structural Conflict.

73. Toulmin, Human Understanding, p. 1.

74. Ruggie analyzes this process in "On the Problem of 'The Global Problematique.'" 
processes of global epistemic politics lie the seeds of the future demand for international regimes. ${ }^{75}$

In short, the institutional-design approach, complemented by a concern with transparency creation, the legitimation struggle, and epistemic politics, can push the heuristic fruitfulness of the regime research program "forward" yet another step, linking it "back" to the study of international organizations.

\section{Conclusion}

In this article, we set out to present a "state of the art" of the field of international organization circa 1985 . Our conclusions can be restated very quickly. In the first section, we tried to dispel the notion that the field has been floundering from one "dependent variable" to another, as academic fashions have dictated. On the contrary, the analytical shifts have been progressive and cumulative and have been guided by an overriding concern with what has always preoccupied students of international organization: how the modern society of nations governs itself.

In the second section we pointed out, however, that the currently ascendant regimes approach is internally inconsistent in a manner that has deleterious effects. The reason for its inconsistency is the tension between its ontological posture and its prevailing epistemological practices. In contrast to the epistemological ideal of positivism, which insists on a separation of "object" and "subject," we proposed a more interpretive approach that would open up regime analysis to the communicative rather than merely the referential functions of norms in social interactions. Thus, what constitutes a breach of an obligation undertaken within a regime is not simply an "objective description" of a fact but an intersubjective appraisal. Likewise, what constitutes reciprocity or reasonableness of behavior within regime contexts is not an issue that can be resolved simply by a monological treatment of "objective information," as is characteristic of a propositional language. For regimes are inherently dialogical in character. To be sure, in circumstances that require little interpretation on the part of the relevant actorsbecause the environment is placid, because shared knowledge prevails, or because coercion determines outcomes-interpretive epistemologies will not be required. But we do not take such occurrences to be broadly representative of contemporary international regimes. For the more general universe of cases, once it was decided that the ontology of regimes consists of an intersubjective basis-and the consensus definition of regimes suggests

75. Haas, "Words Can Hurt You," and Haas, "Why Collaborate? Issue-Linkage and International Regimes," World Politics 32 (April 1980). 
as much-then what Frank Lentricchia has called "spectator epistemology" ipso facto became insufficient. ${ }^{76}$

Finally, in our third section, we identified some linkages between the analytical construct of international regimes and the concrete entities of international organizations. Students of international organization have already assimilated from the organizational design school the lesson that the provision of routine and predictable policy frameworks is not synonymous with the construction of formal hierarchies. An interpretive epistemology would suggest further that international organizations can contribute to the effectiveness of informal ordering mechanisms, such as regimes, by their ability to enhance (or diminish) intersubjective expectations and normatively stabilized meanings, which are the very bases of regimes. International organizations do so, we pointed out, through the modalities of transparency creation, focusing the legitimation struggle, and devising future regime agendas via epistemic politics. Thus reinvigorated, the study of formal organizations may yet come to reinvigorate the practice of formal organizations.

76. Frank Lentricchia, Criticism and Social Change (Chicago: University of Chicago Press, 1983), p. 3. 